\title{
FeCo ve FeCoV Alaşımlarının Metalotermik Yöntem ile Üretilmesi ve Termodinamik Modellenmesi
}

\author{
Mehmet BUĞDAYCI ${ }^{*}$, Ahmet TURAN \\ Kimya ve Süreç Mühendisliği Bölümü, Mühendislik Fakültesi, Yalova Üniversitesi, Yalova \\ (ORCID: 0000-0001-6276-9251) (ORCID: 0000-0002-7578-1089)
}

\begin{abstract}
$\ddot{O} \mathbf{z}$
FeCo alaşımları, yüksek enerji gerektiren ergitme sistemleriyle üretilmekte ve yüksek güç gerektiren uygulamalar ile havacılık sektöründeki motor ve jeneratörlerde kullanılmaktadır. Bu çalışmada ilgili FeCo alaşımlarının, oksitli hammaddelerinden alüminyum redüktan kullanarak metalotermik redüksiyon yöntemi ile üretim parametreleri araştırılmıştır. Metalotermik redüksiyon, ilave enerji gereksinimi olmayan ve kendi iç enerjisi ile gerçekleşen reaksiyonlara dayanan bir tekniktir. Deneysel çalışmalarda demir hammaddesi olarak $\mathrm{Fe}_{2} \mathrm{O}_{3}$ (hematit), kobalt kaynağı olarak $\mathrm{Co}_{3} \mathrm{O}_{4}$ ve redüktan olarak $\mathrm{Al}$ (alüminyum) kullanılmışıtır. Ayrıca, ürün alaşımda kırılganlığını gidermek için şarj karışımına ağırlıkça \%2'lik V (vanadyum) ilavesinin etkisi de incelenmiş ve vanadyum kaynağı olarak $\mathrm{V}_{2} \mathrm{O}_{5}$ kullanılmıştır. Elde edilen alaşımların karakterizasyonlarında $\mathrm{X}$-1şınları floresans spektrometrisi (XRF) ve taramalı elektron mikroskopisi (SEM-EDS) teknikleri kullanılmıştır. Ayrıca redüksiyon çalışmalarının modellemeleri FactSage termokimyasal modelleme programı ile gerçekleştirilmiştir. FeCo-ağ.\%2V üretimi için yapılan deneysel çalışmalarda en yüksek Fe kazanım verimi, Al stokiyometrisinin $\% 105$ olduğu deneysel çalışmada \%95,56 olarak elde edilirken, aynı deneysel çalışmada Co ve V verimleri sırası ile \%95,00 ve \% 87,05 olarak elde edilmiştir. İlgili Co ve V kazanım verimleri de deneysel çalışmalar esnasında elde edilen en yüksek kazanım verimleri olmuştur.
\end{abstract}

Anahtar kelimeler: FeCo, FeCoV, Metalotermik Redüksiyon.

\section{Metallothermic Production of FeCo and FeCoV Alloys and the Thermodynamical Modelling Studies of the Process}

\begin{abstract}
FeCo alloys are produced by means of smelting systems with high energy requirements and, they are used in high power-requiring applications and in engines and in generators for aerospace industry. In the present study, production properties of FeCo alloys were investigated through metallothermic process by using aluminium reductant from its oxide raw materials. Metallothermic reduction is a production technique which is based on the reactions they take place with their internal energy and they do not need any additional energy. In experiments, $\mathrm{Fe}_{2} \mathrm{O}_{3}$ (hematite) and $\mathrm{Co}_{3} \mathrm{O}_{4}$ were used as the $\mathrm{Fe}$ and the $\mathrm{Co}$ sources whereas the $\mathrm{Al}$ (aluminium) was used as reductant. Moreover, the effect of $2 \mathrm{wt} . \% \mathrm{~V}$ addition to final alloys was investigated to enhance the ductility of alloys and, $\mathrm{V}_{2} \mathrm{O}_{5}$ was the raw material to obtain the vanadium. X-ray floresans spectrometry (XRD) and scanning electron microscopy (SEM-EDS) methods were used to characterize produced alloys. Besides, thermodynamical modelling studies were carried out by means of FactSage thermochemical modelling software. In the experiments for the production of FeCo-2wt.\% V, the highest Fe recovery efficiency was obtained as $95.56 \%$ in the experiment with $105 \% \mathrm{Al}$ stoichiometry. In the same experiment, the Co and the $\mathrm{V}$ recovery efficiency ratios were $95.00 \%$ and $87.05 \%$ respectively and, those ratios were the highest values for the Co and the $\mathrm{V}$ recovery in experimental studies.
\end{abstract}

Keywords: FeCo, FeCoV, Metallothermic Reduction.

*Sorumlu yazar: mehmet.bugdayci@yalova.edu.tr

Geliş Tarihi: 15.04.2019, Kabul Tarihi: 19.09.2019 


\section{Giriş}

Demir, \%5,4'lük bir oranla oksijen, silisyum ve alüminyumdan sonra yer kabuğunda dördüncü en çok bulunan elementtir [1]. Dünya'da 62 farkl1 ülkede toplam 1,5 milyar ton civarında ham çelik üretilmektedir. En yüksek üretim Asya'da olup, onu Avrupa Birliği, Kuzey Amerika ve Bağımsız Devletler Topluluğu izlemektedir [2]. Demir ve alaşımlarının üretim ve tüketimi her geçen yıl artmaktadır. Kobalt (Co) önemli bir alaşım elemanı olarak çeliklere ilave edilmektedir. Kobaltın yüksek hız çeliklerinin kesme özellikleri üzerindeki olumlu etkisi ilk olarak 1912'de gözlemlenilmiştir. Güncel olarak, kobaltın çeşitli yüksek hız çeliklerinin kesme, fiziko-mekanik ve teknolojik özellikleri üzerindeki etkisi hakkında birçok veri bulunmaktadır. Kobalt içeren çeliklerin dayanıklılığı basit şekilli kesme takımlarında daha yüksektir (frezeler sert tornalama takım-iş parçası sistemi) [3]. Kobalt ayrıca AC1, AC3 sıcaklığını ve çeliklerin termal iletkenliğini artırmaktadır. Kobalt, yüksek sıcaklıklarda ve manyetik geçirgenlikte gücü artırmak için yüksek hız çeliklerine ilave edilen bir elementtir. Taşıyıcı eleman olarak kullanılan yüksek hız çelikleri, dekarbürizasyona karşı biraz daha fazla eğilime sahiptir ve ani sıcaklık değişimlerine maruz kaldıklarında çatlamaya karşı daha hassastırlar. Ayrıca kobalt içeren çeliklerin kullanımı, mükemmel sertlik özelliklerinden dolayı artış göstermektedir. Soğuk iş kalıp çeliğine Co ilavesi (\% 3 Co'lu çeliklerde olduğu gibi) sertliği arttırır ve kullanılmadığı sınıflarda daha yüksek aşınma direnci sağlar. Aynı şekilde, sıcak iş kalıp çelikleri, daha iyi aşınma direnci ve daha yüksek sicak sertlik değerleri göstermektedirler [3].

FeCo alaşımları, yüksek mıknatıslanma, düşük manyetik zorlanma ve yüksek sıcaklıklarda kararlı yapıları nedeniyle iyi bilinmektedir, bunlar manyetik sensörler, manyetik kayıt ve yüksek güçlü motorlar veya jeneratörlerde yaygın olarak kullanılan en önemli yumuşak manyetik malzemelerden biridir [4-11]. Geleneksel FeCo yumuşak manyetik alaşımlar genellikle elektrik ark ve indüksiyonlu ergitme sistemleri ile metalik haldeki Fe, Co ve V gibi alaşım elemanlarından elde edilmektedir. Döküm sonrasında ideal morfoloji ve yapıyı elde etmek için ısıl işleme tabi tutulmaktadırlar [8,9].

Yüksek güç gerektiren uygulamalar ve havacılık sektöründe kullanılan motor ve jeneratörlerde, yüksek mekanik mukavemete sahip yumuşak manyetik malzemelerin kullanılması bir gerekliliktir. $\mathrm{Bu}$ yüksek mukavemetli yumuşak manyetik malzemeler ile ilgili araştırılmalar son yıllarda yoğunlaşmış ve sonuç olarak önemli gelişmeler elde edilmiştir. Bu çalışmalarda, bahsi geçen uygulamalar için Fe-Co alaşımları, yüksek Curie sıcaklığı, düşük manyeto-kristal anizotropik özelliği, yüksek mukavemeti, mükemmel manyetik özellikleri sebebiyle aday malzeme olarak gösterilmektedir Bu malzemeler yüksek akım yoğunluğu gerektiren uygulamalar için son derece uygundur [9]. FeCo'nun bu benzersiz manyetik özellikleri nedeniyle, malzeme yüksek devirli pompalarda da kullanılabilir [10]. Ağırlıkça \%50 Fe, \%50 Co içeren $\mathrm{FeCo}$ alaşımı çok kırılgan özellik göstermesinden dolayı şekillendirilmesi oldukça güçtür. Alaşımın kırılganlığını gidermek için kompozisyona vanadyum ya da krom ilavesi yapılmasının olumlu etkileri literatürde belirtilmektedir [3].

Yumuşak manyetik malzemeler küçük bir dış mıknatıslanma alanı altında kolayca mıknatıslanabilir ve manyetikleştirilebilir, böylece önemli bir mühendislik malzemeleri sınıfı oluştururlar [8]. Çok önemli ve oldukça sofistike bir mühendislik malzemesi sınıfını oluşturan kalıcı mıknatıslar, buzdolabı parçaları, bilgisayar ve elektronikte kullanılan en gelişmiş mıknatıslara kadar geniş bir yelpazede endüstriyel ve ticari uygulamalara sahiptirler [8]. Genel olarak, yumuşak manyetik malzemeler, 1.1 ile 100000 aralığında yüksek bir başlangıç geçirgenliği ve 0.4-1000 $\mathrm{Am}^{-1}$ aralığında düşük bir mıknatıslanma aralığı ile karakterize edilmektedirler. Bu malzemelerin manyetik özellikleri, güç üretimi ve dağıtımı, aktüatör, manyetik ekranlama, veri depolama ve mikrodalga iletişimi içeren uygulamalar için çok önemlidir [9]. Yumuşak manyetik alaşımlar üç kategoriye ayrılabilir bunlar, metalik alaşımlar, metalik metaller ve seramikler olarak sıralanmaktadırlar. Endüstride kullanılan bazı yumuşak manyetik malzemeler demir, düşük karbonlu çelikler, ferro-silisyum, ferritik çelikler, ferronikel, ferro-kobalt, yumuşak ferritler ve yumuşak manyetik amorf alaşımlardır. Havacılık ve yüksek güç uygulamalarında kullanılan motor ve jeneratörlerin geliştirilmesi için, yüksek mekanik mukavemete sahip yumuşak manyetik malzemeleri kullanmak bir gerekliliktir. Bu yüksek mukavemetli yumuşak manyetik alaşımların araştırılmasında çok sayıda araştırma yapılmıştır ve sonuç olarak önemli gelişmeler sağlanmıştır [7].

Fe-Co alaşımları, modern teknolojide yumuşak ve sert manyetik malzemeler elde etmek için yaygın olarak kullanılmaktadır. Bu alaşımlarda, hem çözünmüş hem de metal olmayan yapıların içinde 
muhteviyatını koruyan oksijenen zararlı empürite olarak karşıya çıkmaktadır. Minimum oksijen konsantrasyonuyla bitmiş metal üretimi, alaşım yapımında ana zorluklardan biridir $[12,13]$.

Mevcut alaşımların manyetik, mekanik ve elektriksel özelliklerinde elde edilen gelişmeler ve yeni malzemelerin keşfedilmesi, yumuşak manyetik malzemeler arasında ciddi bir rekabete sebep olmuştur. FeCo, ticari manyetik malzemeler arasında en yüksek doygunluk manyetizasyonunu sergileyen malzemedir. Ancak kobaltın yüksek maliyetinden dolayı malzemenin kullanım miktarı yaygın değildir. Yüksek doygunluk değerinin sağlamış olduğu avantajlardan ötürü bileşenlerin hacim veya kütlesinin düşürülmesiyle kendine kullanım alanı bulmuştur. Özellikle uçakların jeneratör ve tahrik motorlarının kaplanmasında yumuşak manyetik malzemeler kullanılmaktadır. FeCo burada yüksek servis sıcaklığ 1 sebebiyle tercih edilebilmektedir. Ancak mekanik özelliklerinin geliştirilmesi gerekmektedir. $\mathrm{Bu}$ da 1 sil işlemle ve alaşımlama ile mümkündür $[14,15]$.

Sundar ve arkadaşlarının yaptı̆̆ 1 çalışmada, yüksek indüksiyon ve geçirgenlik özellikleri gösteren stokiyometrik FeCo alaşımlarının keşfine rağmen, alaşımın yüksek maliyeti, şerit formunda üretiminin zor olması ve düşük elektriksel özdirencinin neticesinde ticari uygulamalarda çok kullanım alanı bulamadığı belirtilmiştir [9]. Alaşımın ince şeritler halinde işlenmesi, AC motor uygulamalarında üretilen girdap akım kayıplarını en aza indirmek için gereklidir. Benzer şekilde, alaşımın direncini arttırmak, girdap akım kayıplarını daha da düşürmektedir. İlk kez White ve Wahl, vanadyum ilavesinin stokiyometrik FeCo'nun zayıf süneklik ve düşük elektriksel direnç özelliklerini geliştirdiğini belirtmiştir. Alaşıma ilave edilen vanadyum miktarının, iyi yumuşak manyetik özellikler sergileyebilmesi için ağırlıkça \%3'ün üzerine çıkmaması gerekmektedir. $\mathrm{FeCo}-\mathrm{V}$ alaşımları kontaminasyonlardan kaçınmak için vakum altında dökülmektedir. S, P, N ve O gibi elementlerin varlığı, işlenebilirliğe ve $\mathrm{FeCo}$ alaşımlarının istenilen mekanik ve manyetik özelliklerine zararlıdır. $\mathrm{Bu}$ nedenle konteminasyonların kontrolü gerekmektedir. Bu çalışmada kullanılacak yöntemde kükürt ve fosfor gibi kirliliklerin yapıya girmesi mümkün değildir, çünkü reaktan ve redüktan malzemeler herhangi bir kirlilik içermemektedir. Deneylerin Ar atmosferi altında yapılması durumundaysa $\mathrm{O}_{2}$ konteminasyonun da giderimi mümkün olacaktır [14].

Kahawara çalışmasında FeCo-2\%V alaşımını üretebilmek için malzemelerin metalik formunu $1565^{\circ} \mathrm{C}$ 'de ergitmiş, Fe sıvı metal banyosuna, kobalt ve vanadyum ilaveleri yaparak arzulanan alaşım kompozisyonunu sağlamıştır. Sonrasında 1 sıl işlem uygulayarak uçakların jeneratör ve tahrik motorlarında kullanılmaya uygun mekanik değerlerde alaşım üretimini gerçekleştirmiştir. Deneyler sonucunda FeCo-2V alaşımının sünekliğinin, sadece alaşımın ferritik bir bölgesinden, östenitik bölgeye geçilip soğutulması sonucunda, büyük heterojen tanelerden oluşan yapılar için bile artabileceği belirlenmiştir. Dolayısıyla alaşımın sünekliğine müdahale edebilmek için karbon miktarının çok az olması gerekmektedir. Bu çalışmada kullanılan yöntem vesilesiyle karbon ilave edildiği kadar yapıya girmektedir ve ferritik bölgenin dışına çıkılıp çıkılmaması kontrol altındadır [15].

Lawrence ve arkadaşları ilk olarak FeCo'yu, bakır cevherlerinden elektrolitik yöntemle üretmişlerdir [16]. Toz metalürjisi, bilyeli öğütme, doğrudan birlikte çökeltme yöntemi, yanma dalgası, elektrik ark ergitme, indüksiyonla ergitme, polyol ve kontrollü kimyasal sentez yöntemi FeCo ve nano FeCo alaşımlarını üretmek için kullanılmakta olan yöntemlerdir [17-22].

$\mathrm{Bu}$ çalışmada ilk kez, yukarıdaki üretim yöntemlerine alternatif olarak $\mathrm{CO}_{2}$ salınımı içermeyen ve çevre dostu bir proses olan metalotermik redüksiyon yöntemi ile $\mathrm{FeCo}$ ve $\mathrm{FeCo}-\mathrm{V}$ üretiminin şartları incelenmiştir. Metalotermik redüksiyon, yüksek teknoloji ürünü alaşımların üretiminde kullanılan basit ve düşük maliyetli bir yöntemdir. Yöntemin çalışması, aşırı ekzotermik reaksiyonun tetiklenmesi ile kendiliğinden başlaması ve hammadde karışımında bir dalga şeklinde kendiliğinden ilerlemesi prensibine dayanmaktadır. Bu olayların gerçekleşmesi için reaksiyonun aşırı ısı üretmesi gerekmektedir [23].

Metalotermik redüksiyon ve metalotermik redüksiyon esaslı prosesler (örn. kendiliğinden ilerleyen yüksek sıcaklık sentezi, SHS), geleneksel üretim yöntemlerinden ayırt edilebilecek birçok özelliğe sahiptir. Bunlardan bazıları; kimyasal reaksiyon sonucu salınan yüksek 1sı, yüksek reaksiyon gerçekleşme oranı ve hızıdır $(0,15 \mathrm{~m} / \mathrm{sn}$.) [24]. Bu proseste, karışımın tutuşma sıcaklığına getirilmesi için karışıma ilk 1sı verildikten sonra, reaksiyon harici enerjiye ihtiyaç duymadan kendiliğinden ilerler. Her katmanda açığa çıkan 1sı, bir sonraki reaksiyona girmemiş karışım katmanına geçer ve bölgeyi tutuşturmak için ilk ısıyı oluşturur ve sıcaklığ yükseltir. Uygulama sırasında üretilen yüksek 1sı enerjisi 
miktarı, reaksiyon hızını doğrudan etkiler; artan hız ile oldukça ekonomik ve yüksek verimli bir üretim sağlanır $[25,26]$.

\section{Materyal ve Metot}

\subsection{Materyal}

Metalotermik redüksiyon yöntemi ile demir, kobalt ve vanadyum esaslı alaşımlar üretimi için çalışmalar yapılmıştır. Deneysel çalışmaların ilk aşaması hematit $\left(\mathrm{Fe}_{2} \mathrm{O}_{3}\right)$ ve kobalt oksidin $\left(\mathrm{Co}_{3} \mathrm{O}_{4}\right)$ aluminyum ile reaksiyona sokulup alaşım elde edilmesi, ikinci aşaması ise hematit-kobalt oksit karışımına Al'nin yanısıra $\mathrm{V}_{2} \mathrm{O}_{5}$ ilavesinin eklenmesi ile alaşım elde edilmesini kapsamaktadır. Deneysel çalışmalardaki amaç, karbotermik yöntemle üretilen alaşımların safiyetine uygun kalite standartlarında Co ve V esaslı ferro-alaşımlar elde etmektir. Deneysel çalışmalarda kullanılan ve yüksek safiyete sahip hammaddeler Nanokar firmasından temin edilmiş olup hammaddelerin safiyet ve tane boyutu değerleri Tablo 1'de verilmiştir.

Tablo 1. Deneysel çalışmalarda kullanılan hammaddelerin safiyet ve tane boyutu değerleri.

\begin{tabular}{ccc}
\hline Bileşen & Safiyet,\% & Tane Boyutu \\
\hline $\mathrm{Fe}_{2} \mathrm{O}_{3}$ & 99,50 & $<45 \mu \mathrm{m}$ \\
$\mathrm{Co}_{3} \mathrm{O}_{4}$ & 99,70 & $<38 \mu \mathrm{m}$ \\
$\mathrm{V}_{2} \mathrm{O}_{5}$ & 99,20 & $<45 \mu \mathrm{m}$ \\
$\mathrm{Al}$ & 99,50 & $<45 \mu \mathrm{m}$ \\
\hline
\end{tabular}

\subsection{Metot}

$\mathrm{Bu}$ çalışmada, her bir işlemde olası bazı farklı reaksiyon gelişimleri dolayısıyla üründe olabilecek az da olsa farklılıkların yanı sıra, redüktan olarak kullanılan malzemenin kaybı gibi dezavantajlar olsa da; çok düşük enerji tüketimi (sadece reaksiyonun başlatılması için gerekli başlangıç 1sısı), prosesin birkaç saniye sürede tamamlanması, basit teknoloji gerektiren proses teçhizat gereksinimleri (reaksiyon potası vb.) ve reaksiyonun soğuma aşamasının kontrol altına alınabilmesi olanağı gibi üstünlükleri nedeniyle metalotermik redüksiyon tekniği seçilmiştir. Çalışmalar üç ana başlık altında yürütülmüştür; termodinamik incelemeler, metalotermik deneyler ve karakterizasyon çalışmaları (Şekil 1).

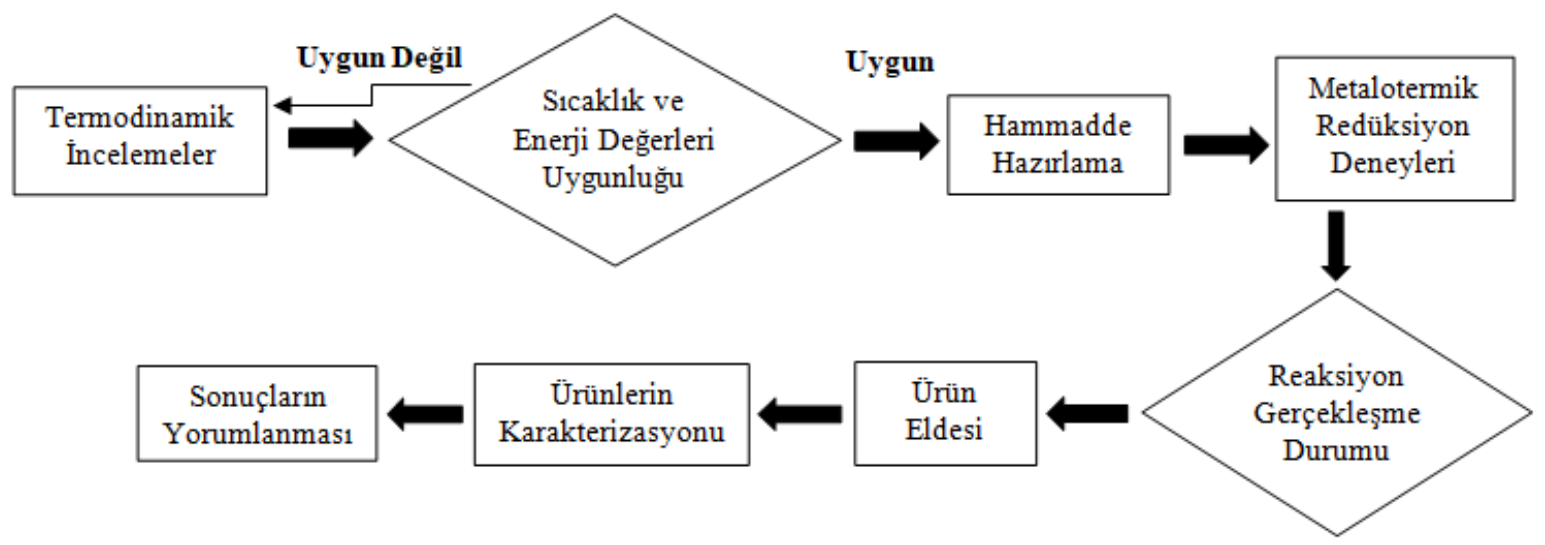

Şekil 1. Deneysel çalışmaların iş akış şeması

Yalova Üniversitesi - Ekstraktif Metalurji ve Geri Dönüşüm Laboratuvarı'nda (EMR-Lab) gerçekleştirilen çalışmalarda, atmosferik koşullar altında metalotermik redüksiyon deneyleri yapılmıştır. Metalotermik redüksiyon yöntemiyle hedeflenen alaşımların üretimi için temel kimyasal reaksiyonların (1) ve (2) numaralı eşitliklerde verilen şekilde olması öngörülmüştür. Farklı hedef bileşimlerine sahip alaşımların üretilmesi sırasında, değişen oranlarda metal oksit ve Al toz karışımları kullanılmıştır. 
$\mathrm{aFe}_{2} \mathrm{O}_{3}+\mathrm{bCo}_{3} \mathrm{O}_{4}+\mathrm{cAl} \rightarrow \mathrm{Fe}_{\mathrm{x}} \mathrm{Co}_{\mathrm{y}}+\mathrm{dAl}_{2} \mathrm{O}_{3}$
$\mathrm{aFe}_{2} \mathrm{O}_{3}+\mathrm{bCo}_{3} \mathrm{O}_{4}+\mathrm{cV}_{2} \mathrm{O}_{5}+\mathrm{dAl} \rightarrow \mathrm{Fe}_{\mathrm{x}} \mathrm{Co}_{\mathrm{y}} \mathrm{V}_{\mathrm{z}}+\mathrm{eAl}_{2} \mathrm{O}_{3}$

Farklı bileşimlerde alaşımların üretilmesine yönelik hazırlanan hammadde toz karışımları toplam $100 \mathrm{~g}$ ağırlığında hassas terazide tartılmış ve karışım 3-eksenli karıştırıcıda $10 \mathrm{dk}$. süre boyunca karıştırılmışıır. Karıştırma işleminden sonra tozlar $105^{\circ} \mathrm{C}$ 'de 1 saat süreyle kurutularak nemden arındırılmış, sonrasında şamot pota içerisine yerleştirilmiştir. Reaksiyonlar, şamot pota içerisine beslenen toz karışımının yüzeyine yerleştirilen W direnç teli üzerinde elektrik akımı geçirilip direnç telinin sıcaklığının artmasıyla reaksiyon tetiklenerek başlatılmıştır. Tetiklemeyle oluşan isı dalgasının hammadde karışımı yüzeyinden pota boyunca kendiliğinden ilerlemesi sonucunda reaksiyon tamamlanmakta ve hızlı soğuma ile katılaşmanın ardından üretilen alaşım ve curuf yoğunluk farkından dolayı kolaylıkla birbirinden ayrılmaktadır. Reaksiyonun şematik görünümü Şekil 2'de verilmiştir.

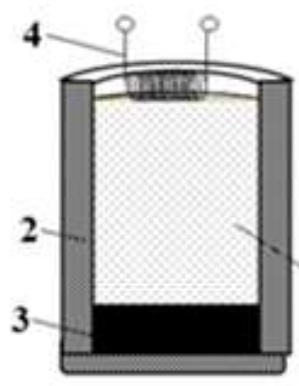

(A)

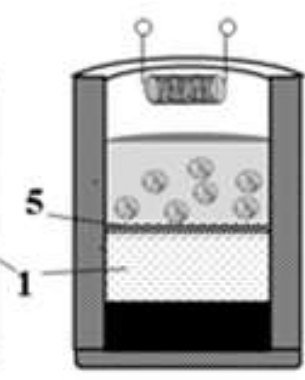

(B)

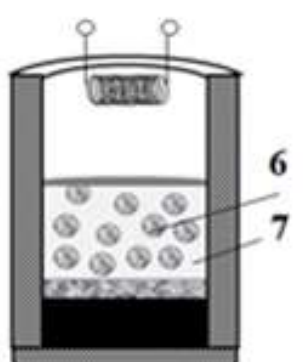

(C)

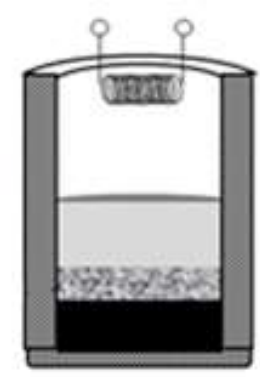

(D)

Şekil 2. Ferro alaşım üretimi için metalotermik proses akış şeması: (A) hammadde karışımının potaya yerleştirilmesi, (B) reaksiyon ilerlemesi, (C) faz ayrılması ve (D) katılaşma [(1) hammadde karışımı, (2) refrakter kalıp, (3) pota tabanı, (4) ateşleme bobini, (5) yanma dalgası, (6) ergimiş halde alaşım granülleri ve (7) ergimiş halde $\mathrm{Al}_{2} \mathrm{O}_{3}$ esasli curuf].

Metalotermik redüksiyon deneylerinin verimleri (3) numaralı eşitliğe göre hesaplanmıştır. İlgili eşitlikte, "\% Metal" alaşımın metal içeriğini simgelerken "Hammadde \% Metal İçeriği" başlangıç karışımındaki metal miktarını göstermektedir.

Verim $=[(\%$ Metal x Alaşım Ağırlı̆̆ı $) /($ Hammadde \% Metal içeriği $)] \times 100$

\subsection{Karakterizasyon Yöntemleri}

Alaşım ve curufların kimyasal kompozisyonunu belirlemek için Thermoscientific Nitel XL2 plus model XRF cihazı kullanılmıştır. Ürün alaşımların mikroyapı görüntüleri LEICA marka optik mikroskop ve Carl Zeiss / Gemini 300 marka-model SEM-EDS cihazı ile alınmıştır.

\section{Bulgular ve Tartışma}

Bir metalin metalotermik yöntem ile indirgenmesi, indirgeyici olarak kullanılan metalin indirgenecek olan metalden oksijen afinitesinin daha yüksek olması durumunda gerçekleşmektedir. Bu durum oksitlerin Ellingham Diyagramına bakarak değerlendirilebilir. Ellingham diyagramı incelendiğinde diyagramın en alt bölgesinde sirasılla kalsiyum, aluminyum ve magnezyumun olduğu görülmektedir. $\mathrm{Bu}$ veriler 1şı̆̆ında bütün metal oksitler bu üç malzemeyle indirgenebilir konumdadır. İndirgenecek metal oksidin, oksijen afinitesiyle, indirgeyici metalin oksijen afinitesi arasındaki fark arttıkça oluşacak olan yüksek enerjiden dolayı reaksiyonun gerçekleşmesi daha kolaydır (Şekil 3). 


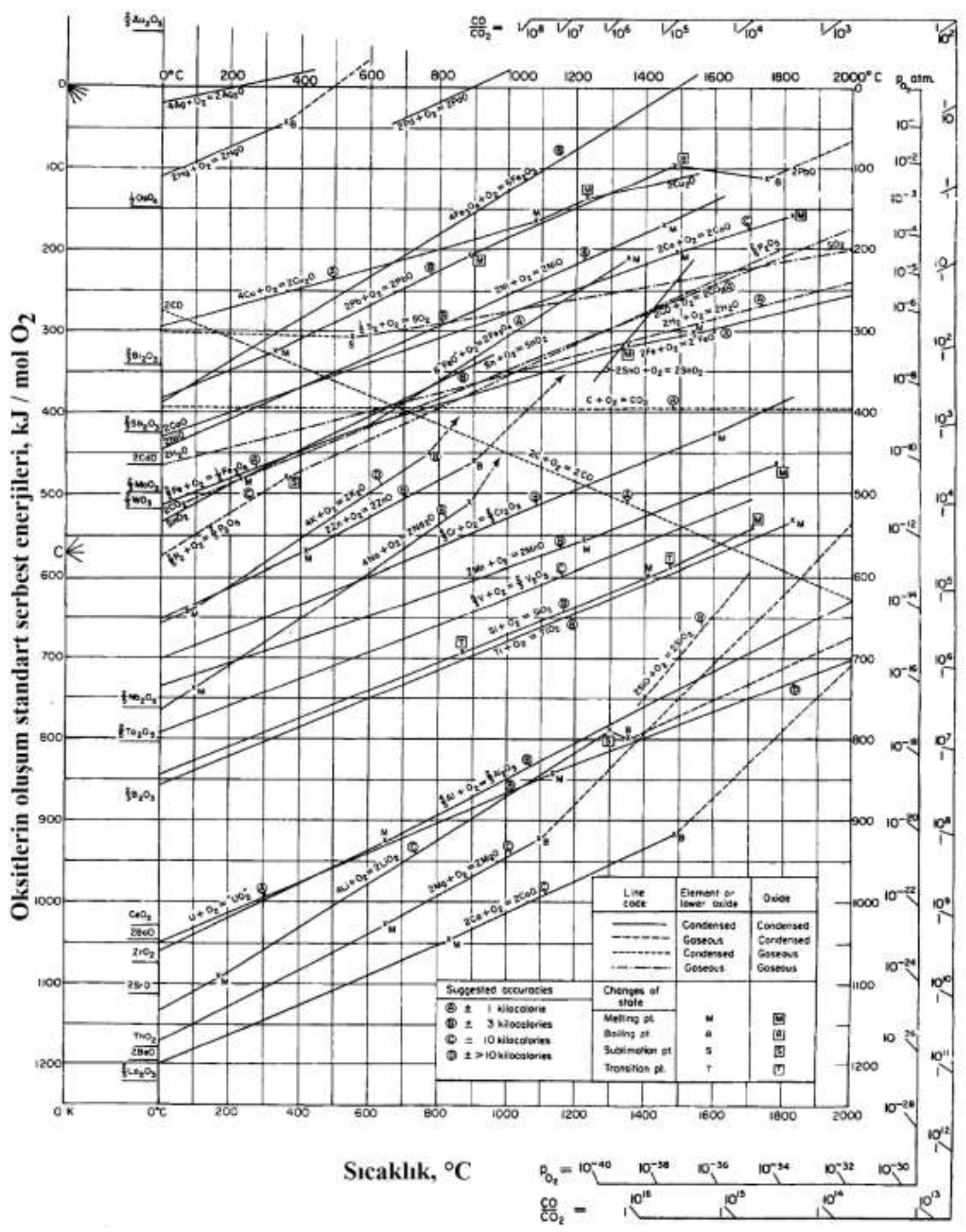

Şekil 3. Ellingham Diyagramı [27].

Metallerin oksijene olan afiniteleri bileşiklerinin oluşum enerjisi olan $\Delta \mathrm{H}$ değeri ile ilişkilidir, bu çalışmada kullanılan metal oksitlerin mol oksijen başına, oluşum entalpi değerleri FactSage 7.1 programıyla belirlenmiş, sonuçlar Tablo 2'de verilmiştir.

Tablo 2. Metal oksitlerin oluşum enerjileri

\begin{tabular}{cc}
\hline Oksit oluşum reaksiyonu & Entalpi Değeri, $\mathbf{\Delta H}_{\mathbf{2 9 8}}$ \\
\hline $4 / 3 \mathrm{Fe}+\mathrm{O}_{2}=2 / 3 \mathrm{Fe}_{2} \mathrm{O}_{3}$ & $-547 \mathrm{~kJ} / \mathrm{mol} \mathrm{O}_{2}$ \\
$3 / 2 \mathrm{Co}+\mathrm{O}_{2}=1 / 2 \mathrm{Co}_{3} \mathrm{O}_{4}$ & $-455 \mathrm{~kJ} / \mathrm{mol} \mathrm{O}_{2}$ \\
$4 / 5 \mathrm{~V}+\mathrm{O}_{2}=2 / 5 \mathrm{~V}_{2} \mathrm{O}_{5}$ & $-617 \mathrm{~kJ} / \mathrm{mol} \mathrm{O}_{2}$ \\
$4 / 3 \mathrm{Al}+\mathrm{O}_{2}=2 / 3 \mathrm{Al}_{2} \mathrm{O}_{3}$ & $-1.118 \mathrm{~kJ} / \mathrm{mol} \mathrm{O}_{2}$ \\
$2 \mathrm{Mg}+\mathrm{O}_{2}=2 \mathrm{MgO}^{2}$ & $-1.202 \mathrm{~kJ} / \mathrm{mol} \mathrm{O}_{2}$ \\
\hline
\end{tabular}


Tablo 2 incelendiğinde, magnezyum ve alüminyumun oluşum entalpi değerlerinin diğer malzemelere kıyasla yaklaşık olarak iki kat fazla bir değerde olduğu görülmektedir. Buna göre demir, kobalt ve vanadyum oksitleri indirgeyebilmek için alüminyum ve magnezyumun kullanımının uygun olduğu belirlenmiştir.

Metalotermik reaksiyonlarda adyabatik sıcaklığın yanı sıra diğer bir önemli parametre spesifik 1S1 değeridir. Spesifik 1sı gram ürün başına açığa çıkan enerji değeridir. Bu değerin $2250 \mathrm{~J} / \mathrm{g}$ ile $4500 \mathrm{~J} / \mathrm{g}$ aralığında olması kontrollü bir reaksiyonun ilerlemesi ve patlamaya bağlı saçılmaya kayıplarının olmaması için bir gerekliliktir. Spesifik 1sı limit değerlerin altında olursa yoğunluk farkından oluşacak olan metal curuf ayrımı gerçekleşememekte, yüksek olması durumunda ise saçılmaya bağlı yüksek oranda metal kayıpları görülmektedir. Bu çalışma kapsamında kullanılan metal oksitlerin metal içeriklerinin alüminyum ile indirgenmesi sonucu açığa çıkan spesifik 1sı ve adyabatik sıcaklık değerleri Tablo 3'te gösterilmiştir. Tablo 3 incelendiğinde, spesifik 1sı değerlerinin V hariç belirlenen limitler içinde olduğu görülmüştür. Hazırlanan başlangıç karışımı göz önüne alındığında V'nin kompozisyona $\% 2$ oranında eklendiği durumda toplam reaksiyonun spesifik ısı değerini arzulanan limitlerin dışına çıkarmayacağı görülmüş ve kendiliğinden ilerleyen kontrollü reaksiyonların elde edileceği ön görülmüştür.

Tablo 3. Metal oksitlerin Al ile reaksiyonları sonucu oluşan entalpi, spesifik 1sı ve adyabatik sıcaklık değerleri.

\begin{tabular}{cccc}
\hline Reaksiyon & Entalpi Değeri $\mathbf{\Delta H} \mathbf{H}^{\mathbf{2 9 8}}$ & Spesifik Isl J/g & $\mathbf{T}_{\text {ad. }}\left({ }^{\mathbf{o}} \mathbf{C}\right)$ \\
\hline $0,5 \mathrm{Fe}_{2} \mathrm{O}_{3}+\mathrm{Al}=\mathrm{Fe}+0,5 \mathrm{Al}_{2} \mathrm{O}_{3}$ & $-424.957 \mathrm{~J} / \mathrm{mol} \mathrm{Al}$ & 3977,9 & 2851,3 \\
$0,38 \mathrm{Co}_{3} \mathrm{O}_{4}+\mathrm{Al}=1,13 \mathrm{Co}+0,5 \mathrm{Al}_{2} \mathrm{O}_{3}$ & $-487.175 \mathrm{~J} / \mathrm{mol} \mathrm{Al}$ & 4153,9 & 2923,5 \\
$0,3 \mathrm{~V}_{2} \mathrm{O}_{5}+\mathrm{Al}=0,6 \mathrm{~V}+0,5 \mathrm{Al}_{2} \mathrm{O}_{3}$ & $-372.673 \mathrm{~J} / \mathrm{mol} \mathrm{Al}$ & 4570,4 & 2910,0 \\
\hline
\end{tabular}

FeCo ve FeCo-V üretimi için yapılan deneylerle eş zamanlı olarak sistemin termodinamik incelemesi de FactSage 7.1 programı yardımıyla gerçekleştirilmiştir. Reaksiyonun başlayıp kendi kendine ilerleyebilmesi için adyabatik sıcaklık önemli bir parametredir ve minimum $1527^{\circ} \mathrm{C}$ olması gerekmektedir. Şekil 4'te FeCo üretimi için çizilen adyabatik sıcaklık grafiği verilirken, Şekil 5 'te FeCoV için çizilen grafik gösterilmiştir. Her iki grafik incelendiğinde sistemin adyabatik sıcaklığının artan Al ilavesiyle belirli bir noktaya kadar yükseldiği $\left(2910^{\circ} \mathrm{C}\right)$, sonrasında düştüğü görülmektedir. $\mathrm{Bu}$ sıcaklık $1527{ }^{\circ} \mathrm{C}$ 'den yüksek olup reaksiyonun başlayabilmesi için yeterli bir değerdir.

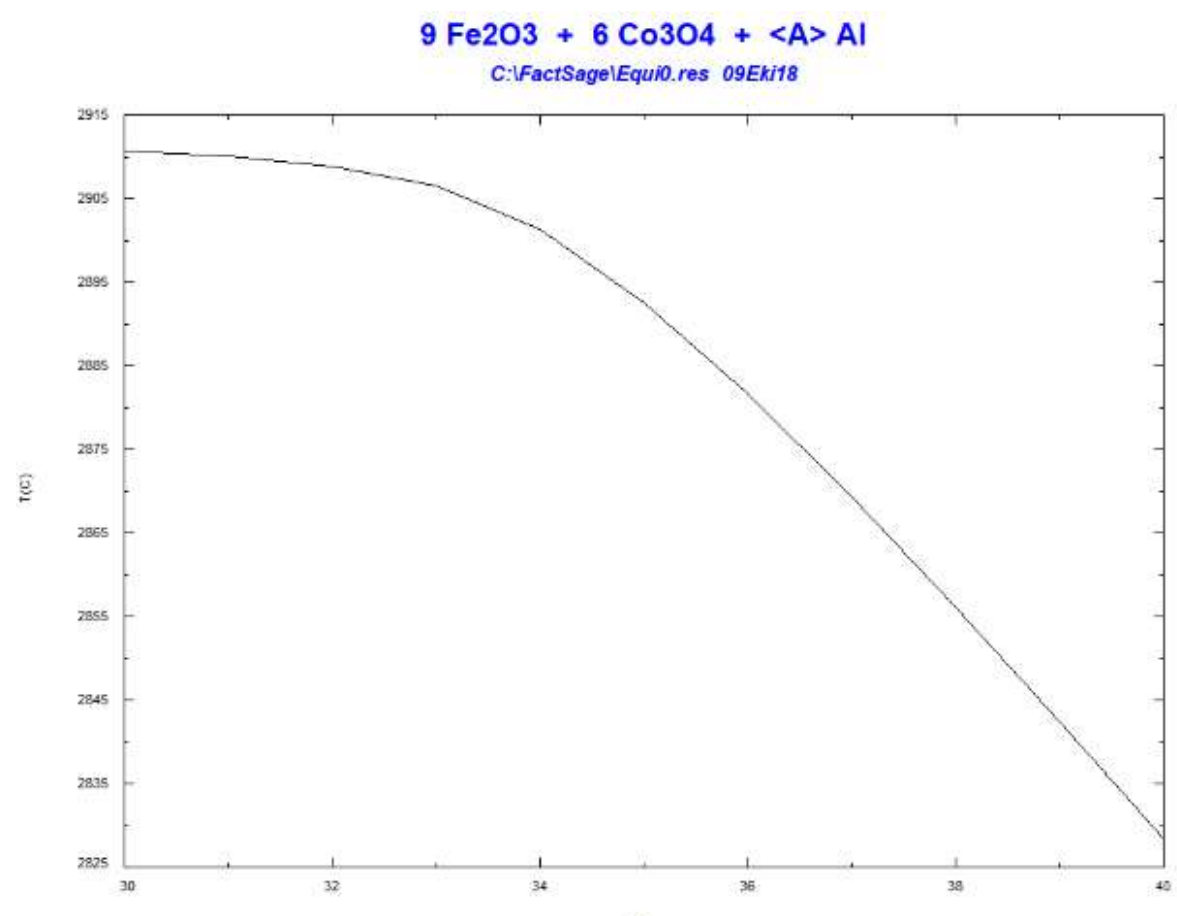

Şekil 4. FeCo Üretiminde değişen Al stokiyometrisiyle elde edilen adyabatik sıcaklık değerleri. 


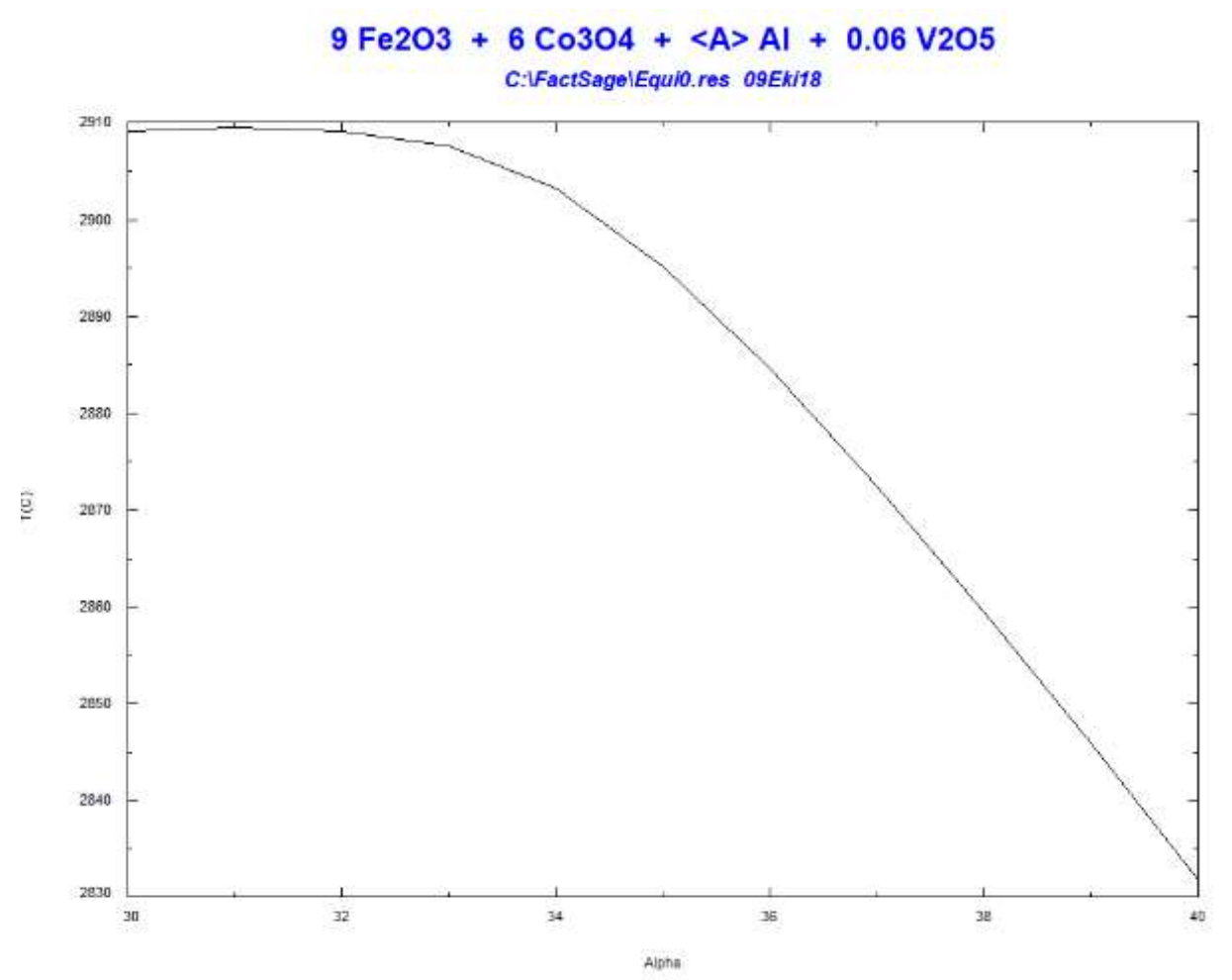

Şekil 5. FeCoV Üretiminde değişen Al stokiyometrisiyle elde edilen adyabatik sıcaklık değerleri.

Sistemin adyabatik sıcaklığının belirlenmesinden sonra değişen alüminyum stokiyometrisiyle her iki alaşımda oluşacak muhtemel fazlar modellenmiștir. Bu aşamada FactSage programının, Gibbs serbest enerjisi minimizatörü mantığıyla çalışan Equlibrium modülünden yararlanılmıştır. Program simüle edilen basınç ve sıcaklık değerlerinde oluşabilecek kararlı fazları göstermektedir. FeCo sisteminden elde edilen sonuçlar Şekil 6'da verilirken, FeCoV sisteminde oluşan muhtemel fazlar Şekil 7'de gösterilmiştir.

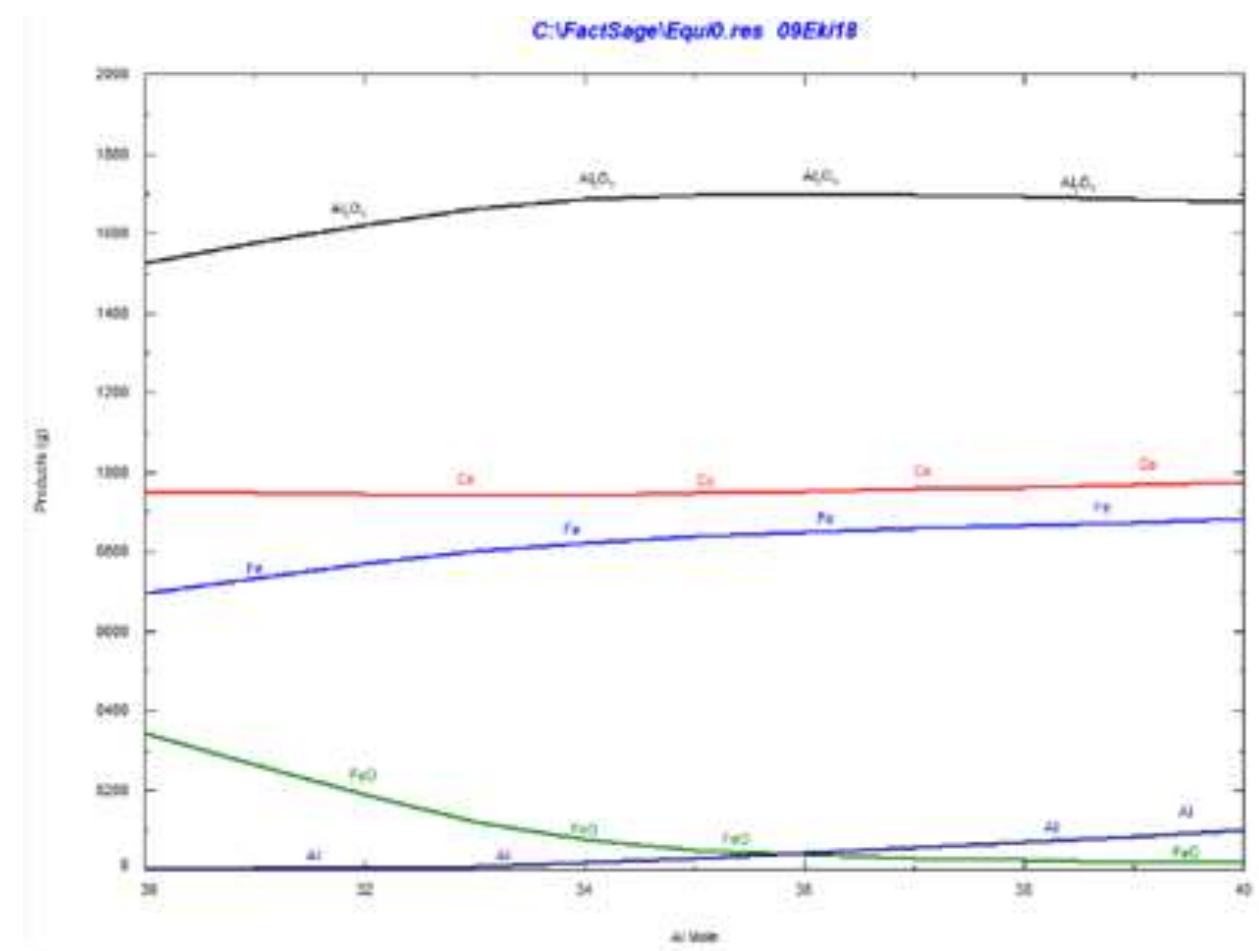

Şekil 6. FeCo Üretiminde değişen Al stokiyometrisiyle elde edilen muhtemel fazlar. 


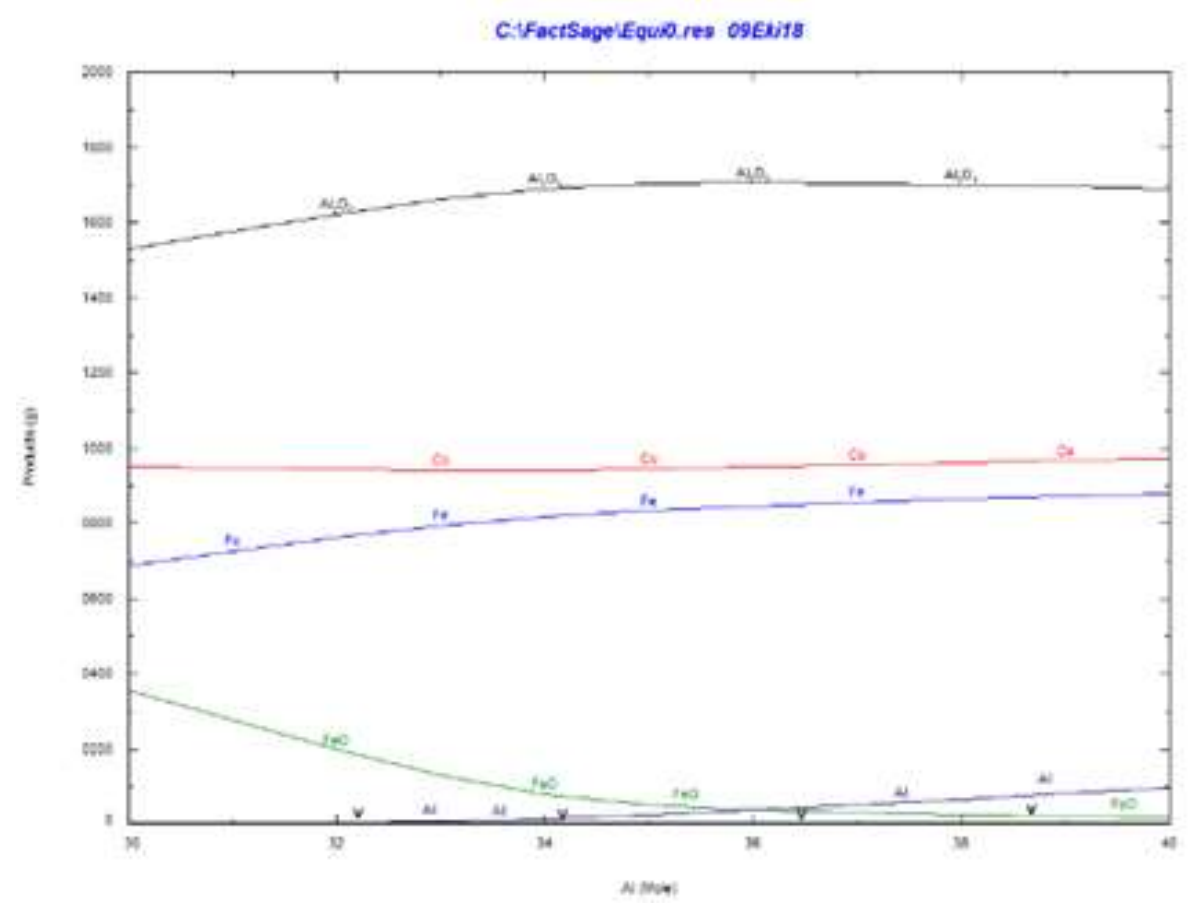

Şekil 7. FeCoV Üretiminde değişen Al stokiyometrisiyle elde edilen muhtemel fazlar.

Şekil 6 ve Şekil 7'ye göre yeterli stokiyometrik oranda Al ilavesiyle hem demir, hem kobalt, hem de vanadyum üretiminin metalotermik redüksiyon yöntemiyle gerçekleştirilebilir olduğu görülmektedir. Alüminyumun her iki grafikte de $\mathrm{Al}_{2} \mathrm{O}_{3}$ formunda gözlemlenmiş, $\mathrm{Fe}$, Co ve V'un oksijenini alarak redükleme işlemini gerçekleştirebilmiştir. 35 mol ve üzerindeki $\mathrm{Al}$ ilavesiyle $\mathrm{Al}_{2} \mathrm{O}_{3}$ 'ün yanı sıra metalik Alüminyumunda kararlı faz olarak oluştuğu belirlenmiştir. Bu sebepten aşırı Al ilavesinin redüksiyonu olumsuz yönde etkilediği belirlenmiştir.

FeCo sentezlemek için gerçekleştirilen deneylerde, demir kaynağ 1 olarak hematit, kobalt kaynağ 1 olarak $\mathrm{Co}_{3} \mathrm{O}_{4}$, redüktan olarak aluminyumun kullanıldığ 1 şarjlar hazırlanmış ve alüminyum stokiyometrisindeki değişimin, FeCo kazanım verimleri üzerindeki etkileri araştırılmış̧ır. Bu çalışmada hedef alaşım olarak Permendur 24 kompozisyonu seçilmiştir, bu alaşım \%24 Co içerirken $\% 76 \mathrm{Fe}$ içermektedir. Permendur 24 üretimi hedeflenen deney setinde \% 90-95-100-110-120 oranlarında değişen stokiyometrik $\mathrm{Al}$ içeren numuneler, $100 \mathrm{~g}$ ağırlığında tartılıp, karıştıııldıktan sonra, etüvde 40 dk. süreyle $105{ }^{\circ} \mathrm{C}^{\prime}$ de bekletilerek nemden arındırılmıştır. Kurutulmuş karışım metalotermik redüksiyonun gerçekleştirildiği bakır potaya şarj edilip, varyak vasıtasıyla reaksiyon gerçekleştirilmiştir. Deney sonucunda elde edilen metalik numune ve curuf, XRF tekniğiyle analiz edilmiş, birbirine tutarlı sonuçlar gözlemlenmiştir. Metal ve cürufların kimyasal analiz sonuçları Tablo 4'te verilmiştir. $\mathrm{Bu}$ sonuçlardan elde edilen metal kazanım verimleri Şekil 8'de paylaşılmıştır.

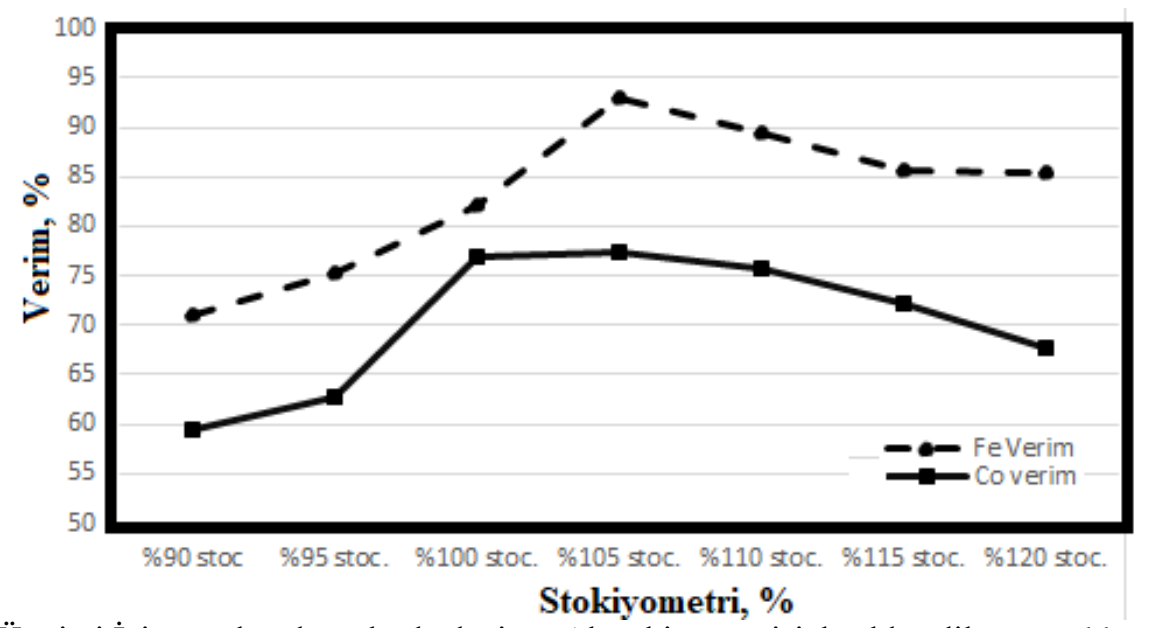

Şekil 8. FeCo Üretimi İçin yapılan deneylerde değişen Al stokiyometrisiyle elde edilen metal kazanım verimleri. 
Tablo 4. FeCo üretimi için gerçekleştirilen deneyler sonucu elde edilen metalin XRF analizi sonuçları.

\begin{tabular}{cccc}
\hline Al Stokiyometrisi & Fe & Co & Al \\
\hline$\% 90$ & 53,92 & 14,27 & 30,81 \\
$\% 95$ & 57,28 & 15,09 & 27,37 \\
$\% 100$ & 62,33 & 18,48 & 19,19 \\
$\% 105$ & 70,60 & 18,60 & 10,40 \\
$\% 110$ & 68,04 & 18,20 & 13,10 \\
$\% 115$ & 65,08 & 17,34 & 16,58 \\
$\% 120$ & 64,95 & 16,25 & 18,20 \\
\hline
\end{tabular}

Tablo 4 ve Şekil 8 incelendiğinde $\% 90$ stokiyometrik bileşimde Fe ve Co verimi sırasıyla $\% 70,94$ ve \%59,45 olarak belirlenirken, bu değerler Al stokiyometrisi \%105'e yükseldiğinde \%92,89 ve \%77,50'e ulaşmıştır. Bu değerden sonra ilave edilen alüminyumun reaksiyon 1sısını düşürerek kendi kendini redükleme eğiliminde olduğu ve metal kazanım verimlerini düşürdüğü belirlenmiştir.

Permendur $24 \mathrm{FeCo}$ alaşımı üretimi için yapılan deneyler gerçekleştirildikten sonra, Permendur $49 \mathrm{FeCoV}$ alaşımı üretimi için çalışmalar gerçekleştirilmiştir. Permendur $49, \% 49 \mathrm{Fe}, \% 49 \mathrm{Co}$ ve $\% 2 \mathrm{~V}$ içermektedir. Bu çalışmalarda ilk deney setinde kullanılan malzemelerin yanı sıra vanadyum kaynağı olarak şarja $\mathrm{V}_{2} \mathrm{O}_{5}$ ilave edilmiş ve ilk deney grubunda yapılan benzer prosedürlerle şarjlar hazırlanmıştır. Bütün reaktanları redükleyebilecek Al miktarı hesaplanmış ve bu miktar \%100 stokiyometrik oran olarak belirlenmiştir. Sonrasında Al stokiyometrisi değiştirilerek deneyler gerçekleştirilmiştir. Elde edilen deneysel sonuçlar Tablo 5 ve Şekil 9'da gösterilmiştir.

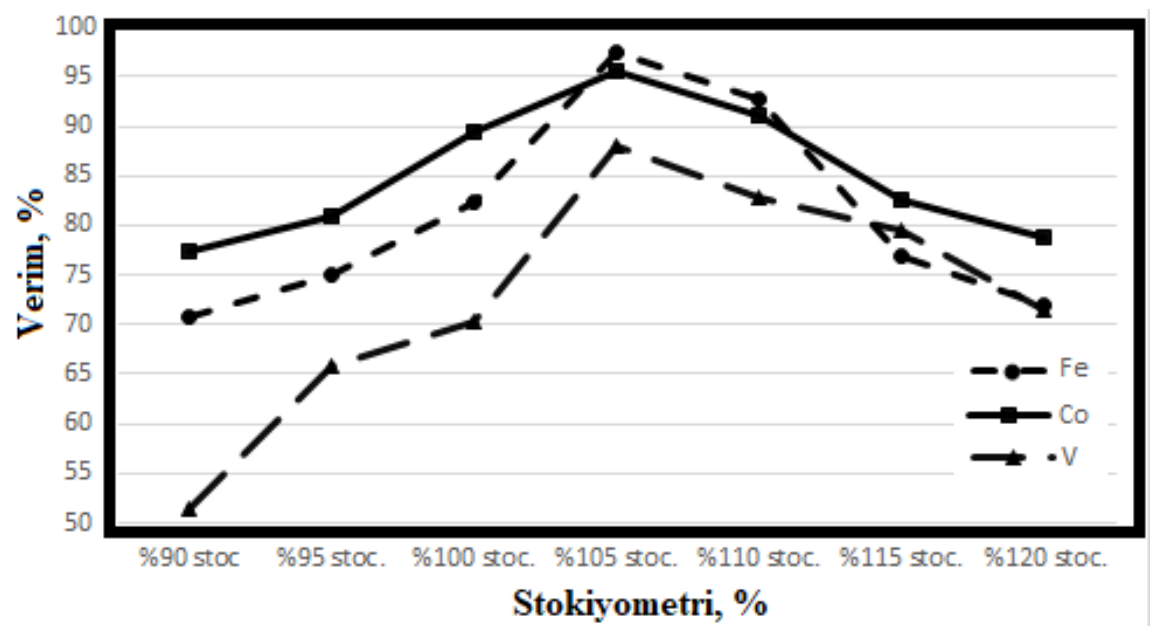

Şekil 9. FeCoV Üretimi İçin yapılan deneylerde değişen Al stokiyometrisiyle elde edilen verimler.

Tablo 5. FeCoV üretimi için gerçekleştirilen deneyler sonucu elde edilen metalin XRF analizi sonuçları.

\begin{tabular}{ccccc}
\hline Stokiyometri & Fe & Co & V & Al \\
\hline$\% 90$ & 38,37 & 34,46 & 0,90 & 25,26 \\
$\% 95$ & 40,10 & 36,50 & 1,15 & 21,34 \\
$\% 100$ & 44,37 & 40,02 & 1,23 & 13,89 \\
$\% 105$ & 47,40 & 43,43 & 1,54 & 7,61 \\
$\% 110$ & 45,12 & 41,34 & 1,45 & 12,05 \\
$\% 115$ & 41,01 & 37,45 & 1,39 & 20,09 \\
$\% 120$ & 39,05 & 34,96 & 1,25 & 23,99
\end{tabular}

$\mathrm{FeCoV}$ üretimi için gerçekleştirilen deneylerin sonuçları incelendiğinde, metal kazanım verimlerinde ilk deney setiyle benzer değişimlerin elde edildiği görülmüştür. Metal kazanım verimleri, Al stokiyometrisinin \%90 olduğu durumdan \%105'e kadar olduğu duruma kadar yükselmiş sonrasında düşüş göstermiştir. Buna ek olarak sarja V ilavesinin, hem Fe, hem de Co oluşumunu teşvik ettiği, bu 
ilavenin reaksiyon ısısını yükselterek daha yüksek verimlere ulaşılmasını sağladığı görülmüştür. Şekil 8 ve Şekil 9 karşılaştırıldığında, ilk deney setinde en yüksek olarak elde edilen \%992,89'luk Fe kazanım veriminin ikinci grup deneylerde \%95,56'ya kadar yükseldiği görülmüş, Co verimi de benzer biçimde \%77,50'den, \% 95,00'a kadar yükselmiş̦tir. Deneyler sonucu elde edilen alaşımdaki vanadyum verimi incelendiğinde, en yüksek verimin \%105 stokiyometrik alüminyum ilavesiyle gerçekleştirilen deneyde $\% 87,05$ 'lik değerle elde edildiği belirlenmiştir.

FeCo eldesi için \% 105 stokiyometrik alüminyum ilavesiyle gerçekleştirilen deneyde elde edilen alaşımın optik mikroskop ve SEM-EDS ile mikroyapı görüntüleri alınmış ve mikrograflar Şekil 10'da verilmiştir. Numune kesilip zımparalandıktan sonra hacimce $\% 50 \mathrm{HCl}-\% 50$ saf su içeren çözeltiyle 30 dakika süreyle dağlanmış, sonrasında incelemeler yapılmıştır. Şekil 10 (A)'ya göre FeCo fazı tane içlerinde homojen bir biçimde dağılmıştır. Şekil 10 (B)'de verilen SEM mikrografının EDS analizinde yapının ağırlıkça \%72,7 Fe, \%20,6 Co ve \%6,7 Al'den oluştuğu tespit edilmiştir.
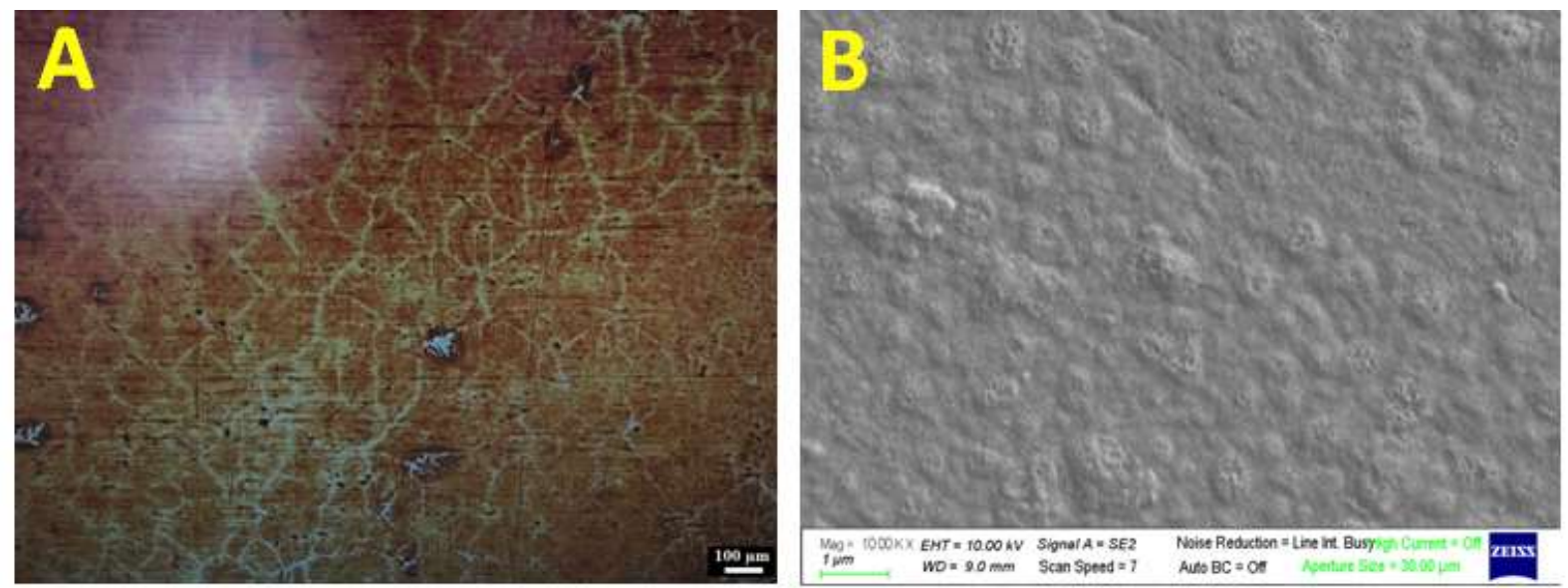

Şekil 10. FeCo üretimi için gerçekleştirilen deneysel çalışamalarda \%105 Al stokiyometrisinde elde edilen alaşımın optik mikroskop (A) ve SEM mikrografları (B).

Deneysel çalışmaların sonucunda elde edilen alaşımların XRF sonuçları incelendiğinde, bütün yapılarda yüksek miktarda Al kaldığı saptanmıştır. Tablo 4 ve Tablo 5'teki Al miktarlarına göre, en yüksek verimin elde edildiği \%105 stokiyometrik Al ilavesi ile gerçekleştirilen deneysel çalışmada V ilaveli deneyde $\mathrm{Al}$ miktarı \%7,61 olarak gözlemlenmiştir. Bu değer bütün kompozisyonlar içerisindeki en düşük Al değeri olmasına rağmen arzu edilen kompozisyonun oluşmasını engellemektedir. Yapılan termodinamik incelemelerde Mg'nin entalpi değerinin alüminyumdan yüksek olduğu görülmektedir. Deneylerin Mg redüktan ile tekrarlanması durumunda arzu edilen kompozisyona daha yakın kimyasal kompozisyonlarda alaşım elde edilebileceği düşünülmektedir.

\section{Sonuç}

$\mathrm{Bu}$ çalışmada Permendur 24 ve Permendur 49 standartlarında FeCo ve $\mathrm{FeCoV}$ alaşımlarının metalotermik redüksiyon yöntemi ile üretimi amaçlanmış, reaksiyon koşulları FactSage 7.1 termodinamik simülasyon programıyla modellenmiştir. Çalışmada metal oksitlerin metal içerikleri alüminyum ile redüklenerek metal kazanım verimleri incelenmiştir. Hem FeCo hem de $\mathrm{FeCoV}$ üretimi için yapılan deneysel çalışmalarda en yüksek metal kazanım verimleri \%105 Al redüktan ilavesi ile gerçekleştirilen çalışmalarda elde edilmiştir. İlgili stokiyometride FeCo kazanımı için yapılan çalışmada $\mathrm{Fe}$ ve Co kazanım verimleri sırasıyla \%92,89 ve \%77,50 olmuştur. $\mathrm{FeCoV}$ üretimi için $\% 105 \mathrm{Al}$ stokiyometrisi ile yapılan deneysel çalışmada Fe verimi $\% 95,56$, Co verimi $\% 95,00$ ve $\mathrm{V}$ verimi $\% 87,05$ olarak hesaplanmıştır. Deney sonuçları incelendiğinde termodinamik incelemelerdeki bulgularla paralel olarak vanadyumun reaksiyon 1 sısını ve bunun sonucunda metal kazanım verimlerini arttırdığ 1 tespit edilmiştir. Metalotermik redüksiyon üretim tekniği her ne kadar hızlı, basit, kolay uygulanabilir ve $\mathrm{CO}_{2}$ salınımı düşük bir üretim yöntemi olsa da indirgeyicinin metale geçmesi, arzu edilen ürünün istenilen standartta üretilememesine yol açabilmektedir. \%105 Al stokiyometrisi ile yapılan deneylerde $\mathrm{FeCo}$ üretiminde alaşımda \%10,40 Al, aynı stokiyometride $\mathrm{FeCoV}$ alaşımında ise \%7,61 $\mathrm{Al}$ ölçülmüştür. $\mathrm{Mg}$ 
gibi farklı indirgeyiciler ve koruyucu atmosfer altında gerçekleştirilen deneyler ile istenilen standartta alaşımların elde edilebileceği öngörülmektedir.

\section{Teşekkür}

$\mathrm{Bu}$ proje Yalova Üniversitesi Bilimsel Araştırma Projeleri Birimi tarafindan 2018/AP/0002 proje numarası ile desteklenmiştir. Yazarlar, BAP birimine mali desteğinden dolayı teşekkürlerini sunarlar.

\section{Yazarların Katkısı}

Makalede yazarların katkısı eşit orandadır. Mehmet BUĞDAYCI (\%50) termodinamik modellemeler, deneylerin yapılması, numune hazırlanması, makalenin yazılması, sonuçların yorumlanması ve revizyonların yapılmasını gerçekleştirmiştir. Ahmet TURAN (\%50) termodinamik modellemeler, karakterizasyon çalışmaları, hammadde temini, makalenin yazılması ve revizyonların yapılmasını gerçekleştirmiştir.

\section{Çıkar Çatışması Beyanı}

Yazarlar arasında herhangi bir çıkar çatışması bulunmamaktadır.

\section{Etik Kurallar}

Yapılan çalışmada, araştırma ve yayın etiğine uyulmuştur.

\section{Kaynaklar}

[1] Önkibar G. 2006. Entegre Demir-Çelik Tesisi Tufalinden Doğrudan Redükleme Yöntemi ile Ham Demir Üretimi. Yüksek Lisans Tezi, Sakarya Üniversitesi, Fen Bilimleri Enstitüsü, Sakarya.

[2] Buğdaycı M. 2014. Krom Nikel İçeren Demirli Alaşımların Metalotermik Yöntemle Üretiminde Tufal Kullanımının Etkisi. İTÜ Yüksek Lisans Tezi, Fen Bilimleri Enstitüsü, İstanbul.

[3] Gulyaev A.P., Kupalova I.K. 1970. Effect of Cobalt on the Structure and Properties of HighSpeed Steels, Consultants Bureau, a division of Plenum Publishing Corporation, 1: 666-671.

[4] Yu R.H., Basu S., Ren L., Zhang Y., Parvizi-Majidi A., Unruh K.M., Xiao J.Q. 2000. High temperature soft magnetic materials: FeCo alloys and composites. IEEE Transactions on Magnetics, 36 (5): 3388-3393.

[6] Sundar R.S., Deevi S.C. 2005. Soft magnetic FeCo alloys: alloy development, processing, and properties. Int. Mater. Rev., 50 (3): 157-192.

[7] Sourmail T. 2005. Near equiatomic FeCo alloys: constitution, mechanical and magnetic properties. Prog Mater Sci., 50: 816-880.

[8] Díaz-Ortiz A., Drautz R., Fähnle M., Dosch H., Sanchez J. M.2006. Structure and magnetism in bcc-based iron-cobalt alloys. Phys. Rev. B, 73: 208-224.

[9] Duckham A., Zhang D.Z., Liang D., Luzin V., Cammarata R.C., Leheny R.L., Chien C.L. 2003. Temperature dependent mechanical properties of ultra-fine grained FeCo-2V. Acta Mater., 51: 4083-4093.

[10] Sundar R.S., Deevi S.C. 2004. Influence of alloying elements on the mechanical properties of FeCo-V alloys. Intermetallics, 12: 921-927.

[11] Yang B., Cao Y., Zhang L., Li R.F., Yang X.Y., Yu R.H. 2014. Controlled chemical synthesis and enhanced performance of micron-sized FeCo particles. Journal of Alloys and Compounds, 615: 322-326.

[12] Mostaan H., Shamanian M., Hasan S., Szpunar J.A. 2015. Response of structural and magnetic properties of ultra-thin $\mathrm{FeCo}-\mathrm{V}$ foils to high-energy beam welding processes. International Journal of Minerals, Metallurgy and Materials, 22 (11): 1190-1198.

[13] Sergeev V.V., Bulygina, T.I. 1980. Hard Magnetic Materials. Energiya, 24: 123-127.

[14] Hilzinger R., Rodewald W. 2013. Magnetic Materials. Erlangen, Publicis Publ. 
[15] White J.H., Wahl C.V. 1932. Workable magnetic compositions containing principally iron and cobalt. US patent No: $1,862,559$.

[16] Kawahara K. 1983. Structures and mechanical properties of an FeCo-2V Alloy. Journal of Materials Science, 18: 3427-3436.

[17] Lawrence F. 1936. Production of Ferrocobalt. Us patent: US2051433.

[18] Koutsopoulos S., Barfod R., Tsamouras D., Eriksen K.M., Fehrmann R. 2017. Synthesis and characterization of iron-cobalt $(\mathrm{FeCo})$ alloy nanoparticles supported on carbon. JALCOM, 725: 1210-1216.

[19] Loginov P., Sidorenko D., Bychkova M., Petrzhik M., Levashov E. 2017. Mechanical Alloying as an Effective Way to Achieve Superior Properties of Fe-Co-Ni Binder Alloy. Metals, 7 (570): $1-14$.

[20] Biasia R.S., Figueiredoa A.B.S., Fernandes A.A.R., Larica C.C. 2007. Synthesis of cobalt ferrite nanoparticles using combustion waves. Solid State Communications, 144: 15-17.

[21] Yang B., Cao Y., Zhang L., Li R.F., Yang X.Y., Yu R.H., 2014. Controlled chemical synthesis and enhanced performance of micron-sized FeCo particles. JALCOM, 615: 322-326.

[22] Molinari A., Marchetti F., Gialanella S., Scardi E., Tiziani A. 1990. Study of the Diamond-Matrix Interface in Hot-pressed Cobalt-based Tools. Materials Science and Engineering, 130: 257-262.

[23] Zehani K., Bez R., Boutahar A., Hlil E.K., Lassri H., Moscovici J., Mliki N., Bessais L. 2014. Structural, magnetic, and electronic properties of high moment FeCo nanoparticles. JALCOM, 591: 58-64.

[24] Weimer A.W. 1997. Thermochemistry and Kinetics. In Carbide, Nitride and Boride Materials Synthesis and Processing. Chapman \& Hall, London, UK, 79-114.

[25] Merzhanov, A.G. 2002. Self-Propagating High-Temperature Synthesis (SHS). ISMAN, Russia.

[26] Munir Z.A., Tamburini U.A. 1989. Self-propagating exothermic reactions: The synthesis of hightemperature materials by combustion. Materials Science Reports, 3 (6): 277-358.

[27] Pacheco M.M. 2007. Self-sustained high-temperature reactions-initiation, propagation and synthesis. PhD thesis, http://repository.tudelft.nl (Erişim Tarihi: 22.08.2019).

[28] http://web.mit.edu/2.813/www/readings/Ellingham_diagrams.pdf (Erişim Tarihi: 22.08.2019). 